\title{
Clarification of the confusion surrounding the generic name Bryomorphe Harv. (Asteraceae: Gnaphalieae), and the new genus Muscosomorphe J.C.Manning
}

\section{Authors}

John C. Manning ${ }^{1,2}$ (d) Rafaël Govaerts ${ }^{3}$ (B)

\section{Affiliations}

${ }^{1}$ Compton Herbarium, South African National Biodiversity Institute, Private Bag X7, Claremont 7735, South Africa.

${ }^{2}$ Research Centre for Plant Growth and Development, School of Life Sciences, University of KwaZuluNatal, Pietermaritzburg, Private Bag X01, Scottsville 3209, South Africa.

${ }^{3}$ Jodrell Laboratory, Royal Botanic Gardens, Kew, Richmond TW9 $3 A E$, United Kingdom

\section{Corresponding Author}

J.C. Manning, e-mail: J.Manning@sanbi.org.za

\section{Dates}

Submitted: 8 February 2021 Accepted: 20 July 2021 Published: 10 September 2021

\section{How to cite this article:}

Manning, J.C. \& Govaerts, R. 2021, 'Clarification of the confusion surrounding the generic name Bryomorphe Harv. (Asteraceae: Gnaphalieae), and the new genus Muscosomorphe J.C.Manning', Bothalia 51(2), a8. http://dx.doi.org/10.38201/btha. abc.v51.i2.8

Copyright: (C) 2021. The Authors Licensee: SANBI. This work is licensed under the Creative Commons Attribution 4.0 International License.
The monotypic genus Bryomorphe Harv. is found to be homotypic with Klenzea lycopodioides Sch.Bip., which is considered to be a later synonym of Dolichothrix ericoides (Lam.) Hilliard \& Burtt, and Bryomorphe is thus a synonym of Dolichothrix. The new genus Muscosomorphe J.C.Manning is proposed to accommodate the species previously included in Bryomorphe as B. aretioides (Turcz) Druce, along with the new combination M. aretioides (Turcz) J.C.Manning.

Keywords: Africa; classification; illegitimate superfluous name; nomenclature; taxonomy.

\section{Introduction}

The genus Bryomorphe Harv. (1863) was established for a single, dwarf species of Gnaphalieae (Asteraceae) from the mountains of the Western Cape, with a characteristic cushion-forming habit, ericoid foliage and radiate capitula. The new name B. zeyheri Harv. (1863) provided for the only (thus type) species in his new genus is unfortunately an illegitimate superfluous name for both Helichrysum aretioides Turcz. (1851) and Klenzea lycopodioides Sch.Bip. (1843) since Harvey (1863) cited both of these names in synonymy (Turland et al. 2017: ICN, Art. 52). The first of these names is typified by Zeyher 2908, which was rather vaguely said to come from the Table and Hottentots Holland mtns, and the latter by Krauss s.n. [610] from the mountains (possibly the Kammanassie Mtns) inland of George. In the protologue to Bryomorphe, Harvey (1863) also cited a third specimen, Roser 42 from the Riviersonderend Mtns above Genadendal.

Druce (1911) recognised that $B$. zeyheri was a superfluous name for $H$. aretioides since both names cited Zeyher 2908 as the type and he therefore provided the combination $B$. aretiodes (Harv.) Druce, overlooking the nomenclatural issues raised by Harvey's (1863) inclusion of the earlier K. lycopodioides in synonymy. The nomenclatural priority of $K$. lycopodioides was finally identified by Levyns (1942), who concurred with Harvey (1863) that all three names seemed to apply to the same species and accordingly provided the combination B. lycopodioides (Sch.Bip.) Levyns as the correct name for the taxon.

This is where matters remained until Koekemoer (2011) realised that not one but two quite distinct species were involved, and that the type of $K$. lycopodioides was in fact conspecific with Dolichothrix ericoides (Lam.) Hilliard \& Burtt (1981). The confusion between $K$. lycopodioides and $H$. aretioides is difficult to explain as the former has appressed, scale-like leaves and discoid capitula, 
as was highlighted by Koekemoer (2011), who also provided detailed descriptions of both taxa. Koekemoer (2011) accordingly placed K. lycopodioides in synonymy under $D$. ericoides and recognised the later combination $B$. aretioides (Harv.) Druce as the correct name for the illegitimate $B$. zeyheri Harv., and the type of the genus Bryomorphe.

Unfortunately, Koekemoer (2011) incorrectly identified Roser 42 (TCD) as the holotype of $B$. zeyheri and so overlooked the nomenclatural implications for the genus Bryomorphe of the illegitimacy of the name B. zeyheri. These were identified by Rafaël Govaerts, principal contributor to the World Checklist of Selected Plant Families at Kew, and are addressed here.

\section{Results and nomenclature}

Firstly, the type of Bryomorphe is not $B$. aretioides but is in fact $B$. zeyheri and thus $K$. lycopodiodes. This is by reason of $B$. zeyheri being an illegitimate superfluous name for K. lycopodioides (Turland et al. 2017: ICN, Art. 52.1). A name, unless conserved (Art. 14) or sanctioned (Art. 15), is illegitimate and is to be rejected if it was nomenclaturally superfluous when published, i.e. if the taxon to which it was applied, as circumscribed by its author, definitely included the type of a name that ought to have been adopted, or of which the epithet ought to have been adopted, under the rules. The possible argument that Harvey (1863) excluded the type of $K$. lycopodioides from his circumscription of $B$. zeyheri and thus from Bryomorphe (Turland et al. 2017, ICN: Art. 7.5) is refuted by his words "Schultz (Bip.) places this plant in his genus Klenzea ...." (Harvey 1863: line 34). The type of both $B$. zeyheri and thus of the genus Bryomorphe is thus Krauss 610, which is the type of $K$. lycopodioides. In consequence of this, the genus Bryomorphe becomes a nomenclatural synonym of Dolichothrix.

Furthermore, the name Bryomorphe Harv. (1863) is antedated by the very similar Bryomorpha Kar. \& Kir. (1842) (Caryophyllaceae), which, although not strict homonyms, might be considered confusingly similar (Turland et al. 2017, ICN: Art. 53.2 Ex. 8). Harvey (1863) was evidently unaware of this when he described Bryomorphe, but although he pointed it out later (Harvey 1894), the implications on the legitimacy of the name have escaped attention until now.

Molecular analyses (Bayer et al. 2000; Bengston et al. 2011) place Dolichothrix in a clade with Lachnospermum Willd., Metalasia R.Br., Phaenocoma D.Don. and other satellite genera, whereas Bryomorphe aretioides is retrieved as a member of a separate clade that includes Amphiglossa DC., Disparago Gaertn., Elytropappus Cass. and Stoebe L. Following the current taxonomy, therefore, it is necessary to recognise a new genus for $B$. aretioides, and the generic name Muscosomorphe is proposed here, along with the new combination M. aretioides.

\section{The new genus Muscosomorphe}

Muscosomorphe J.C.Manning, gen. nov. Bryomorphe sensu Koekemoer in Bothalia 41: 325 (2011), non Harv. (1863). Type species: M. aretioides (Turcz.) J.C.Manning

[Bryomorphe sensu Harv., Thesaurus Capensis $2: 33$ (1863), pp., excluding type Klenzea lycopodioides]

Dwarf, cushion-forming shrublets. Leaves ascendingincurved, imbricate, linear, adaxial surface tomentose with longitudinally striate hairs, adaxial surface lachnate. Capitula heterogamous, terminal, 1 to 3 at branch tips, partially concealed among leaves. Involucral bracts multiseriate, outer bracts ovate, foliaceous distally, inner bracts linear to narrowly oblong, scarious, rounded apically with large lateral wings clasping florets. Receptacle alveolate. Ray florets 6 or 7, female, lamina 3-lobed, white. Style branches obtuse, sweeping hairs not tufted. Disc florets 7 to 9, bisexual, corolla purple. Anthers basally tailed. Style branches truncate, sweeping hairs tufted. Cypselas terete, laevigate; pappus setae \pm 15 to 30 , free, barbed in lower four fifths, densely plumose distally, occasionally interspersed with clavate cells.

M. aretioides (Turcz) J.C.Manning, comb. nov. Helichrysum aretioides Turcz. in Bulletin de la Sociéte Impériale des Naturalistes de Moscou 24: 79 (1851). Bryomorphe aretioides (Turcz.) Druce in Second Supplement to Botanical Society \& Exchange Club of the British Isles, Report for 1916, 4: 611 (1917). Type: South Africa, Western Cape: summits of Table and Hottentots Holland mtns, Zeyher 2908 (KW-1000916, holo.-image!; K-415093-image!, P-21335 and 21336-images!, PRE!, S-06-14625image!, SAM!, TCD, iso.).

Etymology: From the Latin muscosus moss-like, alluding to the cushion-forming habit and to the generic name Bryomorphe that was previously used by Harvey (1863).

\section{New synonyms in Dolichothrix}

Dolichothrix Hilliard \& Burtt in Botanical Journal of the Linnean Society 82: 221 (1981). Type species: D. ericoides (Lam.) Hilliard \& Burtt

Bryomorphe Harv., Thesaurus Capensis 2 : 33 (1863) [non Bryomorpha Kar. \& Kir. (1842)], syn. nov.; Harv. in Flora Capensis 3: 277 (1894). Type: B. zeyheri Harv., nom. illeg. = B. lycopodioides (Sch.Bip.) Levyns 
D. ericoides (Lam.) Hilliard \& Burtt in Botanical Journal of the Linnean Society 82: 221 (1981). Xeranthemum ericoides Lam., Encylopédie méthodique. Botanique 3: 240 (1789). Type: South Africa, Western Cape: Cape of Good Hope, Sonnerat s.n. (P-LAM, holo.). [For full synonymy see Koekemoer (2011: 325).

Klenzea lycopodioides Sch.Bip. in Walpers, Repertorium botanices systematicae 2: 973 (1843). Bryomorphe zeyheri Harv., Thesaurus Capensis
2: 33, t. 51 (1863), nom. illeg. superfl. Bryomorphe lycopodioides (Sch.Bip.) Levyns in Journal of South African Botany 8: 283 (1942). Type: South Africa, Western Cape, Oudtshoorn (3322): inter rupes summo montium prope Roodewal, dist. George in Promontorio bonae spei [among rocks on mountain summit near Roodewal, George Dist., Cape of Good Hope], Jan 1839, Krauss 610 (P-21330, holo.-image!; P-21329-image!, TUB-005310)-image!, iso.).

\section{References}

Bayer, R.J., Puttoch, C.F. \& Kelchner, S.A., 2000, 'Phylogeny of South African Gnaphalieae (Asteraceae) based on two noncoding chloroplast sequences', American Journal of Botany 87: 259-272.

Bengston, A., Anderberg, A. \& Karis, P., 2011, 'Phylogeny and generic delimitation of the Metalasia clade (AsteraceaeGnaphalieae)', International Journal of Plant Sciences 172: 1067-1075, https://doi.org/10.1086/661294.

Druce, G.C., 1917, Nomenclatural notes: chiefly African and Australian, Second Supplement to Botanical Society \& Exchange Club of the British Isles, Report for 1916, vol 4: 601-653.

Harvey, W.H., 1863, Bryomorphe zeyheri, Thesaurus capensis 2: 33, Hodges \& Smith, Dublin.

Harvey, W.H., 1894, Compositae, In Harvey, W.H. \& Sonder, W., (eds), Flora capensis 3: 44-530, L. Reeve \& Co., Kent.

Hilliard, O.M. \& Burtt, B.L. 1981. Some generic concepts in Compositae-Gnaphalieae. Botanical Journal of the Linnean Society 82: 181-232.

Karelin, G. \& Kirilow, J., 1842, Generum plantarum novarum ex ordine compositarum, rossiae indigenorum IV, Bulletin de la Société impériale des naturalistes de Moscou 15: 124-180.
Koekemoer, M., 2011, Bryomorphe and Dolichothrix (Asteraceae: Gnaphalieae-Relhaniinae): taxonomy and nomenclature, Bothalia 41: 324-326, https://doi.org/10.4102/abc. v29i1.572.

Lamarck, J.P.B.A.P.M. de, 1789, Encylopédie méthodique. Botanique, vol. 3, Pancouke, Paris.

Levyns, M.R., 1942, Some changes in nomenclature III, Journal of South African Botany 8: 282-284.

Schultz Bipontinus, C.H., 1843, Compositae, In W.G. Walpers, Repertorium botanices systematicae 2: 973, Friderici Hofmeister, Leipzig.

Turczaninow, N.S., 1851, Synanthereae quaedum hucusque indescriptae, Bulletin de la Sociéte Impériale des Naturalistes de Moscou 24: 59-95.

Turland, N.J., Wiersema, J.H., Barrie, F.R., Greuter, W., Hawksworth, D.L., Herendeen, P. S., Knapp, S., Kusber, W.-H., Li, D.-Z., Marhold, K., May, T.W., Mcneill, J., Monro, A.M., Prado, J., Price, M.J. \& Smith, G.F. (eds.), 2018, International Code of Nomenclature for algae, fungi, and plants (Shenzhen Code) adopted by the Nineteenth International Botanical Congress Shenzhen, China, July 2017, Regnum Vegetabile 159, Koeltz Botanical Books, Glashütten. 